\title{
DNA Markers and Genomic Evaluation in Animal Breeding
}

\author{
Glazko Valeriy ${ }^{1 *}$, Kosovsky Gleb Yu $^{2}$ and Glazko Tatiana $\mathrm{T}^{1}$ \\ ${ }^{1}$ KA Timiryazev Russian State Agrarian University, Moscow Agrarian Academy, Russia \\ ${ }^{2}$ FSBSI SRI of Fur Farming and Rabbit Breeding Industries n.a. V.A. Afanasyev, Russia
}

Submission: September 18, 2017; Published: October 03, 2017

"Corresponding author: Glazko Valeriy I, KA Timiryazev Russian State Agrarian University, Moscow Agrarian Academy, Russia, Email: vigvalery@gmail.com

Keywords: Molecular genetic markers; Single nucleotide polymorphisms (SNP); Genes of quantitative traits (QTL); Epigenomics; Exo and epigenotype

\section{Summary}

The search for universal molecular-genetic markers, polymorphism of which would allow reliably predict the desired development of economically valuable traits in farm animals remains the most actual problem during centuries. The generation of marker signs, from phenotypic to modern DNA markers changed, but the challenge of the absence of adequate markers existed. Thanks to the development of methods of genomics and epigenomic becomes clear that only joint genotyping on the structural and regulatory sequences can be created more successful methods for the solution of this problem. This review discusses the generation methods of genetic marking of economically important traits and the dependence of their success from the regulation of gene expression - epigenomic variation.

\section{Mini Review}

'Full genomic evaluation' inclusion in the prediction of animals' breeding value (without evaluation by progeny) can significantly reduce the time between generations when animals can be used in breeding work. The essence of this reduction is that, for example, in dairy cattle bull-calf locus plurality genotyping is used; bull-calves with the closest SNP genotypes of bulls with a high breeding index (estimated by progeny) are selected and then the semen of these selected bull-calves (at the age of one and a half years) are used for cow insemination. This method has been called 'genomic selection'. The economic effectiveness of this approach is obvious. But it will be realized only if complex SNP genotypes, typical for groups of bulls with a high breeding index, are universally associated with the desired manifestation of economically valuable traits in the offspring of such bulls, obtained under different eco-geographical conditions and in different breeds (in different genomic environments).

At the same time, experimental data have been being accumulated indicating that the breeding indexes of the Holstein breed bulls, estimated by the daughters born in different ecogeographical regions, differ significantly from each other and, moreover, contribute different genotypic and ecotypic components to variability [1-4].

Attempts to find genes or genomic elements which polymorphism is closely related to the variability of economically valuable traits, originated in A. Serebrovsky's works, who called such genes 'signalias', aiming that they can be used as 'signals' to predict the desirable development of phenotypic traits. Being used as such 'signalias' in genotyping blood groups were developed, then electrophoretic variants of proteins appeared, and with the development of polymerase chain reaction methods in the 1980s microsatellites, DNA markers were revealed.

The term -Quantitative Trait Loci, or QTL came to hand suggesting that 'signalia' DNA could be closely linked to genes contributing greatly to the desired phenotypic manifestation of the traits. It is not difficult to see that the task formulated more than 100 years ago is the same, only methods and targets of genotyping have been changing.

The search for QTL using DNA markers began more than 30 years ago, consistently developed by the method of increasing DNA markers density on chromosomes first at the level of microsatellite loci, now with the help of millions of SNP. 
The first mapping of major genes of quantitative traits (Quantitative Trait Loci - QTL) in dairy cows of Holstein breed by means of genotyping at microsatellite loci was performed by Michael Georges and co. [5]. The increase in the number and density of SNP genotyped and the analysis of their relationships with the characteristics of milk production performance received a high rate of development after introduction of microarrays into experimental studies [6-12]. Genomic maps of the SNP distribution have been created for cattle, including 705243 sites distributed across all autosomes [13].

A generalization of the search for genomic regions (genomic 'artificial selection fingerprints') associated with the variability of the characteristics of dairy and meat productivity, carcass traits and the specificity of the coloration was carried out. 37 cattle breeds (Bos taurus) were analyzed. A total of 409 such genome areas were identified on 29 autosomes, 232 of which (57\%) were breed-specific and were found only in one breed, $134(33 \%)$ were observed in a limited number of breeds (from two to four breeds) and only 39 regions ( $9 \%$ ) were detected in five or more breeds [14].

The program '1000 Bull Genomes Consortium' (consortium of 1000 genomes of bulls) has been developed in which 20 countries participants have collected totally 1577 full-genome bull sequences $[15,16]$. Within the framework of the program, comparative analysis of 432 genomes of bulls of 13 breeds from 16 countries using 4 million revealed single nucleotide polymorphisms (SNP) was carried out [15]. As a result of the performed hierarchical cluster analysis based on the calculation of the Manhattan distances, the data were obtained indicating that representatives of the same breed can fall into different clusters and vice versa, representatives of different breeds can form a common cluster. The largest number of SNPs involved in differentiation between bulls were found on chromosome 6 (in which the cluster of casein genes is localized), the smallest - in chromosome X. Based on the studies performed, the authors conclude that the functional groups of genes that were the target of artificial and natural selection in the process of domestication, animal's migration and breed formation, are associated with energy metabolism and control of the stages of animal development.

Connection between SNP and such characteristics as total milk yield, fat and protein percentage point) in the group of Northern dairy breeds have been studied [17]. Ayshires of Finland, red cattle of Denmark and Sweden were included in the group of Northern dairy breeds. The regions of chromosomes 5 , $14,23,25$ and 26 were associated with the variability in milk fat percentage point; chromosomes 5, 14, 16, 19, 20 and 25 with a total milk yield; chromosomes 5, 14 and 25 - with protein percentage point. Statistically significant associations were identified for 227 genes for fat percentage point; for 72 genes for total milk yield and for 30 genes - for protein percentage point. In most cases, the most closely associated SNPs with the desired manifestation of milk production performance characteristics are localized in introns or in intergenic spaces.

The authors concluded that the difficulty of identifying direct links between the manifestation of phenotypic traits and SNP genotypes could be overcome in relation with the revealing the functional gene networks and metabolic pathways into which they are involved.

To increase the efficiency of genomic domains labelling, which polymorphism could be used to solve genomic selection problems, a new generation of markers to SNP is attracted, based on the study of polymorphism of the short copies of DNA fragments (less than 400 nucleotide pairs) (Copy Number Variability - CNV) and their genomic distribution [18].

A direct comparison of the results of complete sequencing of the genomes of 62 bulls of three cattle dairy breeds (Holstein, Montbeliard, Normandy) made it possible to see the high level of CNV polymorphism in different genomic regions [19,20]. A total of 547 deletions, 410 tandem duplications, associated with the variability of small genomic areas (CNVs) were identified. 941 large deletions associated with the deletion of one of the gene family were also found out, 10 of them being single-copy genes. Some of the identified structural variants were localized in areas recognized as regions of localization of the main genes of quantitative traits of milk productivity. There is a different frequency of occurrence of SNP in duplicate areas compared to single copies (in duplicate areas, the SNP frequency is higher than in single-copy areas).

It has turned out that these two approaches (SNP and $\mathrm{CNV}$ ) to polylocus genotyping of the cattle genomes do not lead to unambiguous results either. So, in the Holstein breed, chromosomal domains of QTL genes were detected by using the microsatellite locus polymorphism estimates and SNP. In 82 of such domains where CNV was detected, only 17 overlapped with SNP. In 20 chromosomal domains of QTL localization, CNV was present, but not SNP. Based on the studies performed, the authors conclude that it is necessary to use SNP and CNV together to solve the problems of including genomic selection in traditional selection methods [18].

Thus, the accumulated results testified the absence of universal links between complex genotypes according to SNP and CNV and the variability in the manifestation of economically valuable traits and their dependence on the conditions of breeding animals and their pedigree affiliation. At the same time, such polylocus genotyping (genomic scanning) is a costly and rather complicated procedure, and its results are difficult to interpret. It is necessary to emphasize the fact that, as a rule, the structural and functional features of the sites of localization of SNP and CNV revealing, linked to QTL, their potential predisposition to polymorphism remain unknown.

Another method of marking polymorphisms of different genomic regions, similar to $\mathrm{CNV}$, has appeared, but with a reduced 
number of nucleotides included in the evaluation - insertions and deletions (indels), 1 to 49 base pairs (bp) [21]. The authors carried out the comparative analysis of the polymorphism of the indices in two groups of Holstein bulls - with a high and low pedigree index, estimated by the dairy efficiency of daughters. Bulls were full- or half-sibs. There are 3,625 indles distinguishing bulls with high and low tribal values. About 1,137 of them were localized in 767 annotated structural genes, and only $5(0.138 \%)$ were present in the exons. Further, the authors compared the localization of the identified indles with known QTL; linked with SNP for protein and fat characteristics of milk production, as well as with the corresponding metabolic pathways, and identified polymorphic indles in 11 genes that potentially affect the characteristics of milk production (FCGR2B, CENPE, RETSAT, ACSBG2, NFKB2, TBC1D1, NLK, MAP3K1, SLC30A2, ANGPT1, UGDH).

At the same time, a large number of investigations have appeared drawing attention to the fact that attempts to find out the universal DNA markers which polymorphism is associated with the variability of economically valuable traits don't take into account the point that phenotypic features have certain development dynamics, and different limiting (or key) genes may present at different time options. For example, Stracken et al. [22] obtained clear experimental data suggesting that the most pronounced associations between the variability of total milk yield, milk fat and polymorphism of the DGAT1 enzyme were found out after the lactation peak, but the casein gene polymorphisms - at early stages of lactation.

Recently a fundamentally new concept has been formed to identify genetic elements that could become more effective approach to the early prediction of animal breeding value, based on the epigenetic variability targets study. This concept considers the phenotype as a result of the interaction between the actual 'genetic texts' (nucleotide sequences) and the factors that influence the realization of genetic information (conditions of breeding and reproduction, microbiome, pollutants, pathogens). It has been found that, as a rule, metabolic pathways, the variability of which is associated with variability of milk production performance characteristics, in particular, are regularly involved in the functional characteristics of the immune system [23].

Some researchers pay attention to the fact that the base designated as an exophenotype (or phenotype typically named) is endophenotype formed as a result of interaction between genome and environmental factors (that is the result of the interaction between genome and epigenome). It has been assumed that endophenotype is formed due to the interaction of different levels of realization of the hereditary material, such as transcriptome, proteome, metabolome, microbiome, and nonlinear links forming between them (for example, single changes in the transcriptome can lead to multiple changes in the metabolome and vice versa); as well as each level can be influenced by environmental factors directly [24].
The epigenome involves processes such as DNA methylation, histone modifications, chromatin remodeling and involving in regulation of gene expression other molecules that can transmit epigenetic information, including various families of RNA, in particular microRNAs [25].

So far the spectrum of genes and gene networks have been described, the regulation of which in modern, highly productive cattle breeds is fundamentally different from ancient ancestral forms, due to differences in the targets of the microRNAs action in more than 1600 structural genes involved in various metabolic pathways, including number genes of immune system [26]. Expression profiles of various microRNAs involved in the regulation of structural genes belonging to different metabolic pathways, in particular, key to the functions of the immune system, at different stages of lactation of cows $[27,28]$ have been revealed.

Thus, it is coming into the open that only the selection of DNA markers closely related to the regulation of various metabolic pathways may allow solving the problem posed more than 100 years ago by Russian researchers - identifying 'signalias' that permit predicting economically valuable traits desired in farm animal breeds at their early development stages.

\section{References}

1. Hammami H, Rekik B, Bastin C, Soyeurt H, Bormann J, et al. (2009) Environmental sensitivity for milk yield in Luxembourg and Tunisian Holsteins by herd management level. J Dairy Sci 92(9): 4604-4612.

2. Hammami H, Rekik B, Soyeurt H, Bastin C, Bay E, et al. (2009) Accessing genotype by environment interaction using within- and across-country test-day random regression sire models. J Anim Breed Genet 126(5): 366-377.

3. Hammami H, Rekik B, Soyeurt H, Bastin C, Stoll J, et al. (2008) Genotype $\mathrm{x}$ environment interaction for milk yield in Holsteins using Luxembourg and Tunisian populations. J Dairy Sci 91(9): 3661-3671.

4. Hammami H, Rekik B, Soyeurt H, Ben Gara A, Gengler N (2008) Genetic parameters for tunisian holsteins using a test-day random regression model. J Dairy Sci 91(5): 2118-2126.

5. Georges M, Nielsen D, Mackinnon M, Mishra A, Okimoto R, et al. (1995) Mapping quantitative trait loci controlling milk production in dairy cattle by exploiting progeny testing. Genetics 139(2): 907-920.

6. Cole JB, Wiggans GR, Ma L, Sonstegard TS, Lawlor TJ, et al. (2011) Genome-wide association analysis of thirty one production, health, reproduction and body conformation traits in contemporary U.S. Holstein cows. BMC genomics 12: 408.

7. Guo J, Jorjani H, Carlborg O (2012) A genome-wide association study using international breeding-evaluation data identifies major loci affecting production traits and stature in the Brown Swiss cattle breed. BMC genetics 13(1): 82 .

8. Jiang L, Liu J, Sun D, Ma P, Ding X, et al. (2010) Genome wide association studies for milk production traits in Chinese Holstein population. PloS one 5(10): e13661.

9. Mai M, Sahana G, Christiansen F, Guldbrandtsen B (2010) A genomewide association study for milk production traits in Danish Jersey cattle using a $50 \mathrm{~K}$ single nucleotide polymorphism chip. J Anim Sci 88(11): 3522-3528.

10. Meredith BK, Kearney FJ, Finlay EK, Bradley DG, Fahey AG, et al. (2012) Genome-wide associations for milk production and somatic cell score in Holstein-Friesian cattle in Ireland. BMC genetics 13(1): 1. 
11. Minozzi G, Nicolazzi EL, Stella A, Biffani S, Negrini R, et al. (2013) Genome wide analysis of fertility and production traits in Italian Holstein cattle. PLoS One 8(11): e80219.

12. Schopen G, Visker M, Koks P, Mullaart E, van Arendonk J, et al. (2011) Whole-genome association study for milk protein composition in dairy cattle. Journal of dairy science 94(6): 3148-3458.

13. Zhao F, McParland S, Kearney F, Du L, Berry DP (2015) Detection of selection signatures in dairy and beef cattle using high-density genomic information. Genetics Selection Evolution 47: 49 .

14. Gutiérrez-Gil B, Arranz JJ, Wiener P (2015) An interpretive review of selective sweep studies in Bos taurus cattle populations: identification of unique and shared selection signals across breeds. Front Genet 6: 167.

15. Chung NC, Szyda J, Frąszczak M (2017) Population Structure Analysis of Bull Genomes of European and Western Ancestry. Sci Rep 7: 40688.

16. Daetwyler HD, Capitan A, Pausch H, Stothard P, van Binsbergen R, et al. (2014) Whole-genome sequencing of 234 bulls facilitates mapping of monogenic and complex traits in cattle. Nature Genetics 46(8): 858865

17. Iso-Touru T, Sahana G, Guldbrandtsen B, Lund MS, Vilkki J (2016) Genome-wide association analysis of milk yield traits in Nordic Red Cattle using imputed whole genome sequence variants. BMC Genet 17: 55.

18. Xu L, Cole JB, Bickhart DM, Hou Y, Song J, et al. (2014) Genome wide CNV analysis reveals additional variants associated with milk production traits in Holsteins. BMC Genomics 15: 683.

19. Boussaha M, Esquerré D, Barbieri J, Djari A, Pinton A, et al. (2015) Genome-Wide Study of Structural Variants in Bovine Holstein, Montbéliarde and Normande Dairy Breeds. PLoS ONE 10(8): e0135931.

20. Boussaha M, Michot P, Letaief R, Hozé C, Fritz S, et al. (2016) Construction of a large collection of small genome variations in French dairy and beef breeds using whole-genome sequences. Genet Sel Evol 48(1): 87.

21. Jiang J, Gao Y, Hou Y, Li W, Zhang S, et al. (2016) Whole-Genome Resequencing of Holstein Bullsfor Indel Discovery and Identification of Genes Associated with Milk Composition Traits in Dairy Cattle. PLoS ONE 11(12): e0168946.

22. Strucken EM, Laurenson YCSM, Brockmann GA (2015) Go with the flow-biology and genetics of the lactation cycle. Front Genet 6: 118.

23. Edwards SM, Thomsen B, Madsen P, Sorensen P (2015) Partitioning of genomic variance reveals biological pathways associated with udder health and milk production traits in dairy cattle. Genetics Selection Evolution 47: 60 .

24. Te Pas MFW, Madsen J, Calus MPL, Smits MA (2017) The Importance of Endophenotypes to Evaluate the Relationship between Genotype and External Phenotype. Int J Mol Sci 18(2): 472.

25. Ibeagha-Awemu EM, Zhao X (2015) Epigenetic marks: regulators of livestock phenotypes and conceivable sources of missing variation in livestock improvement programs. Front Genet 6: 302.

26. Braud M, Magee DA, Park SDE, Sonstegard TS, Waters SM, et al. (2017) Genome-Wide microRNA Binding Site Variation between Extinct Wild Aurochs and Modern Cattle Identifies Candidate microRNA-Regulated Domestication Genes. Front Genet 8: 3.

27. Do DN, Li R, Dudemaine PL, Ibeagha-Awemu EM (2017) MicroRNA roles in signalling during lactation: an insight from differential expression, time course and pathway analyses of deep sequence data. Sci Rep 7: 44605.

28. Wang D, Liang G, Wang B, Sun H, Liu J, et al. (2016) Systematic microRNAome profiling reveals the roles of microRNAs in milk protein metabolism and quality: insights on low-quality forage utilization. Sci Rep 6: 21194.

\begin{tabular}{l} 
Your next submission with Juniper Publishers \\
will reach you the below assets \\
- Quality Editorial service \\
- Swift Peer Review \\
- Reprints availability \\
- E-prints Service \\
- Manuscript Podcast for convenient understanding \\
- Global attainment for your research \\
- Manuscript accessibility in different formats \\
( Pdf, E-pub, Full Text, Audio) \\
- Unceasing customer service \\
Track the below URL for one-step submission \\
https://juniperpublishers.com/online-submission.php \\
\hline
\end{tabular}

